\title{
Coastal scenic assessment: unlocking the potential for coastal tourism in rural Pakistan via Mediterranean developed techniques
}

\author{
Zia Ullah • David Johnson • Anton Micallef • \\ Allan T. Williams
}

Received: 29 April 2009/Revised: 01 August 2009/Accepted: 5 November 2009

(C) Springer Science + Business Media B.V. 2009

\begin{abstract}
Originally developed within the Mediterranean, a tested coastal management and planning tool was applied outside the region to evaluate its international scope, with particular reference to a less developed country. Seven coastal sites in Pakistan were investigated for their scenic values through a 26 item checklist grouped as physical and human parameters analysed though weighted parameters and fuzzy logic matrices. With respect to a five-class evaluation system, results indicated: Jiwani, Miani Hor and Pasni-Astola Island as extremely attractive natural sites with very high landscape value (classified as Class 1 sites); Mubarak village as an attractive natural site with high landscape value (classified as a Class 2 site); Kaka pir village, Harjana village and Keti Bandar as having little outstanding landscape features or with urban environment and classified as Class 3 sites. Rural and/ or urban environmental influences were observed to be critical factors which influenced major human parameters that ultimately affect sites' scenic classification. However, not-
\end{abstract}

Z. Ullah

Southampton Solent University,

Southampton SO14 0RD, UK

D. Johnson

OSPAR Commission,

Carew street,

London, UK

\section{A. Micallef $(\bowtie)$}

Euro-Mediterranean Centre on Insular Coastal Dynamics, International Environment Institute, University of Malta, MSD 2080, Malta

e-mail: anton.micallef@um.edu.mt

\section{A. T. Williams}

Swansea Metropolitan University,

Mt Pleasant,

Swansea SA1 6ED, UK withstanding natural attraction, unless political and social development barriers are tackled in conjunction with recognising areas that possess inherent tourism potential, economic potential is unlikely to be realised.

Keywords Coastal scenery · Scenic evaluation · Pakistan . Mediterranean Sea

\section{Introduction}

Travel and tourism constitute the world's largest industry (WTO 2001). In many regions, they play a major role in generating employment and consequently emerge as highly important socio-economic drivers. Beaches have been indicated to be one of the major factors for the tourism market (Lencek and Bosker 1998; Houston 2002). In the coastal zone habitat, they are used by more people than any other recreational zone (Clark 1996). As the focal point of coastal recreation and sightseeing, good beaches are worth billions in tourist revenue and can even cause adjacent land to increase in value (Leatherman 2001).

The Mediterranean area is the world's leading tourism region, where the tourism industry has been described as being responsible for $6 \%$ of net job entries for the period $2000-2009$, an average of $12 \%$ of the region's exports (goods \& services) and an increase of international tourist expenditure forecast from US\$96m in 1970 to US\$576 in 2000 (Benoit and Comeau 2005). Many coastal tourism studies (see e.g. Morgan and Williams 1995; Morgan 1996; Micallef et al. 1999; Unal and Williams 1999) have shown that coastal scenery can provide competitive advantages especially in rural and remote regions.

Tourism is playing a critical role in boosting the dwindling economy of Pakistan. This sector contributed 
US\$ 303.5 million in 2006 to the country's economy, of which foreign tourism accounted for US\$260.1million and domestic tourism for US\$43.4 million (Tourism in Pakistan 2006). Meagre information is available on coastal tourism of the country, the only reference point being the Karachi Coastal Recreation Development Plan 1990-2000, which only provides information about the origin of coastal tourists (Table 1). However, current political instability and its associated safety and security concerns for foreign tourists are major threatening factors for the tourism industry. Regardless of this situation the country is still concentrating on multimillion coastal tourism projects focusing on the provision of services through infrastructure development and targeting high income groups or international tourists. For example, two mega coastal tourism projects: Defence Officers Housing Authority (DHA) Water Front Development Project and Diamond Bar Island City Project are in progress along the urban coast of Karachi, Sindh province. DHA project was launched in 2003 by DHA in partnership with foreign investors and will be completed in 2011 with a total cost of US\$ 622,557,246 (DHA-Waterfront Developments Project-Master Plan 2003), while, Diamond Bar Island City Project announced as a joint venture between the Federal Government of Pakistan and the Emmar group-UAE in September 2006, will be completed at an estimated cost of US\$ 43,135 billion (Najam 2007).

The Coastal Scenic Evaluation technique, originally developed within a Mediterranean context, (e.g. Spain, Malta), has since been applied outside of this region, especially in developed countries, for example, UK, USA, New Zealand, Ireland, Australia, New Zealand, Japan (see Ergin et al. 2004 and references therein). Additionally, it has been applied in bordering Mediterranean developing countries i.e. Morocco, Tunisia, and Turkey (respectively, Williams and Ergin 2006; Micallef and Williams (in press); Ergin et al. 2003a). Positive results indicated that the evaluation criteria assessed does indeed represent a wide scope of applicability to coastlines outside of the Mediterranean region and in developing world countries.

Table 1 Coastal visitors to Karachi coast, Sindh, and their origin (source: Coastal Recreation Development Plan 1990)

\begin{tabular}{lrrr}
\hline Origin & \multicolumn{3}{c}{ Visitors $(000)$} \\
\cline { 2 - 4 } & \multicolumn{1}{c}{1988} & $1995^{\mathrm{a}}$ & $2000^{\mathrm{a}}$ \\
\hline Karachi (Local) & 111.3 & 175.4 & 251.2 \\
Up-Country (National) & 9.8 & 12.5 & 15.3 \\
Foreigners & 1.5 & 2.6 & 4.0 \\
Total & $\mathbf{1 2 2 . 6}$ & $\mathbf{1 9 0 . 5}$ & $\mathbf{2 7 0 . 5}$ \\
\hline
\end{tabular}

${ }^{\mathrm{a}}$ Forecasts numbers
In this paper, the technique has been applied for the first time in the context of a developing Asian country, Pakistan, which is currently bedevilled by political problems that have decimated its tourist trade. This opens new perspectives in analyzing potential for coastal tourism development. The application of the Mediterranean-born technique to the Pakistan coastline was carried out to assess and strengthen the techniques' claim for international applicability and hopefully, to bolster future coastal tourism in that country.

Pakistan is situated in South Asia at $23^{\circ}-35^{\prime}$ to $37^{\circ}-05^{\prime}$ north latitudes and $60^{\circ}-50^{\prime}$ to $77^{\circ}-50^{\prime}$ east longitudes and covers approximately $803,940 \mathrm{~km}^{2}$. It has a circa $900 \mathrm{~km}$ coastline along the Arabian Sea in the south and is bordered by Afghanistan and Iran in the west, India in the east and China in the far northeast (Fig. 1). The coastline is mostly bare desert with a variety of landforms such as sand beaches, rock cliffs, headlands, bays, deltas, estuaries, and mud flats with mangrove vegetation.

At present, coastal tourism development in Pakistan is only focused on man-made attractions whilst the tourist values of natural resources and its associated scenic grandeur is much less realised. In this case study, coastal scenic evaluation assessments of seven ecologically sensitive areas (Jiwani, Miani Hor, Pasni-Astola Island, Mubarak village, Kaka Pir village, Harjana village and Keti Bandar) were individually calculated via fuzzy logic analysis, and the major factors influencing their scenic value identified.

\section{Methodology}

Coastal scenic evaluation via fuzzy logic analysis is a checklist technique, which utilises 26 coastal scenic assessment parameters grouped as physical and human factors sets (for detail see Ergin et al. 2002, 2003b, 2004, 2006). All parameters were attributed a value ranging from a low (1) to high rating (5). Based on evaluation of each parameter, final value divides coastal scenery into distinct classes: Class 1 scenery (extremely attractive natural sites) has $\mathrm{D}$ values $\geq 0.85$; Class 2 , between 0.85 and 0.65 ; Class 3 , between 0.65 and 0.4 ; Class 4 , between 0.4 and zero; Class 5 (very un attractive, intensively developed urban) below zero (Fig. 2). The maximum-minimum values of $D$ are +2 and -2 respectively. The curve breaks are site independent and occur in ALL countries where the technique has been applied. Curve break points based on the midpoint change of slope, allowed a division of sites into five main classes, where Class 1 and Class 5 were within the lowest 15 th percentile and top 85 th percentile, respectively, when D criteria percentile values were graphed on a normal plot. (Fig. 3) Break-point statistical distributions were tested for a Gaussian (normal) distribution that would 
Fig. 1 Map of Pakistan showing coastal provinces of Sindh and Balochistan and localities of Jiwani, Gwadar and Pasni. Source: http://www.lib. utexas.edu/maps/middle east and_asia/pakistan_pol_2002.jpg (site visited 3 Feburary 2006)

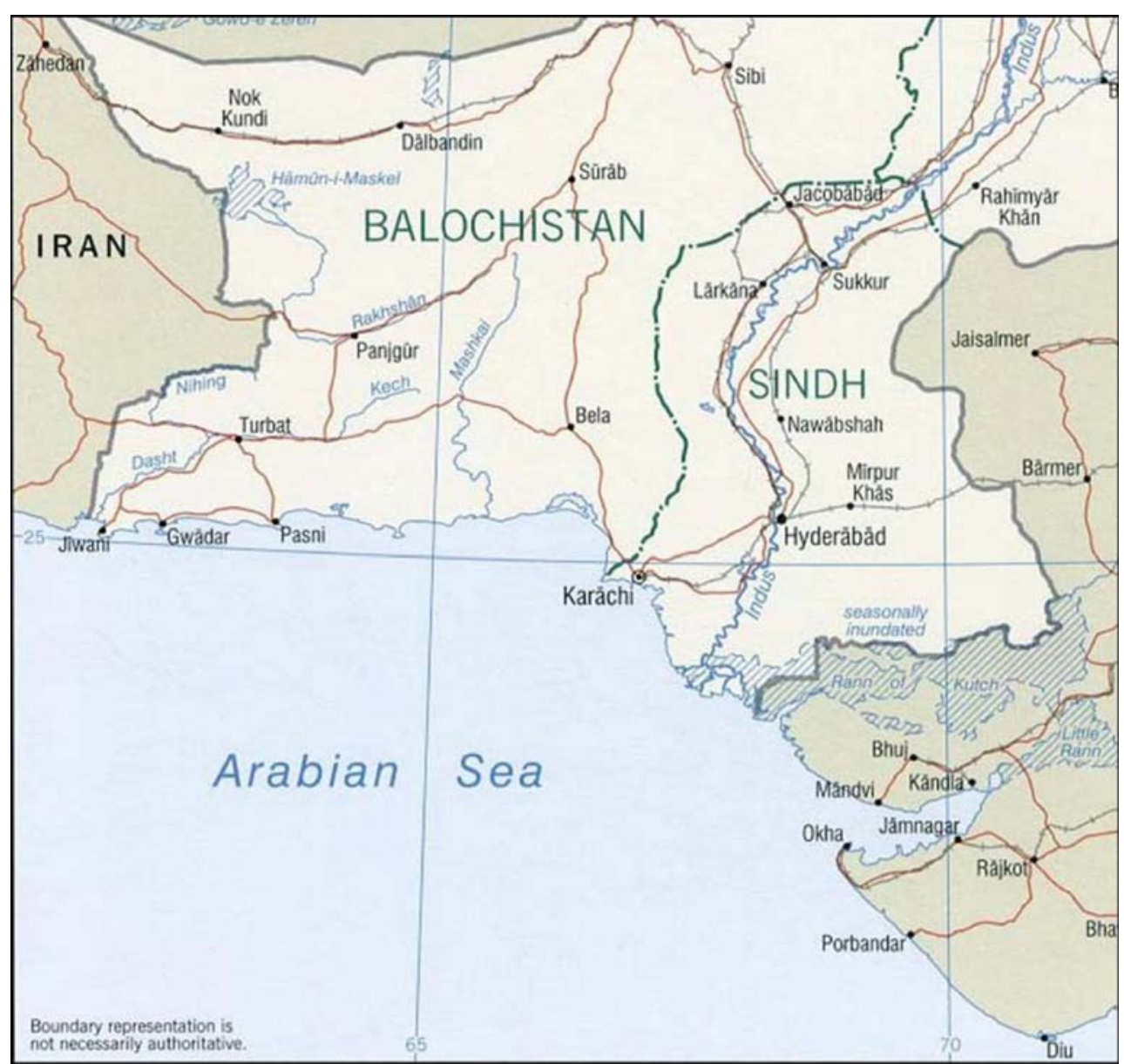

and 6 provide examples for the sites of Jiwani, Mubarak village and Kaka Pir village. The histograms provide a visual summary of both physical and human parameters, and are useful for immediate assessment of the high rated and low rated attributes, while weight averages of attributes delineated relative comparison of physical and human parameters. Similarly, membership degree vs. attribute curve present overall scenic assessment over the attributes, where curve interpretation is based on the skew, a curve skewed to the right hand side reflects high scenic value, for

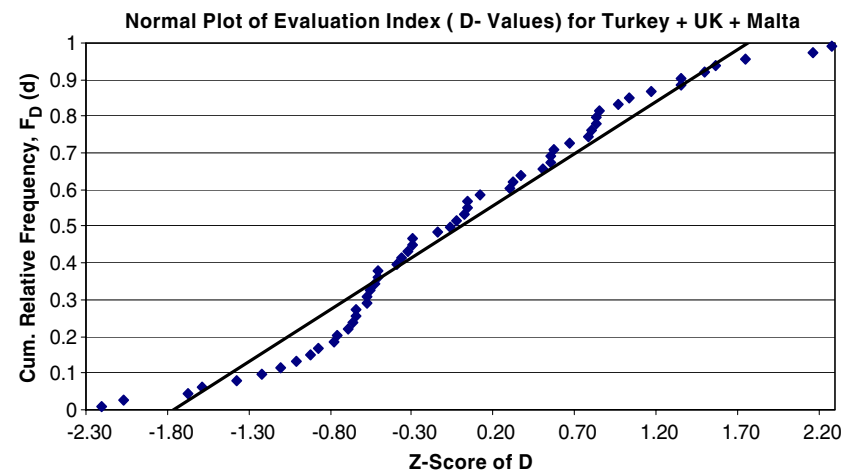

Fig. 3 Normal plot of D value distributions 
(a)

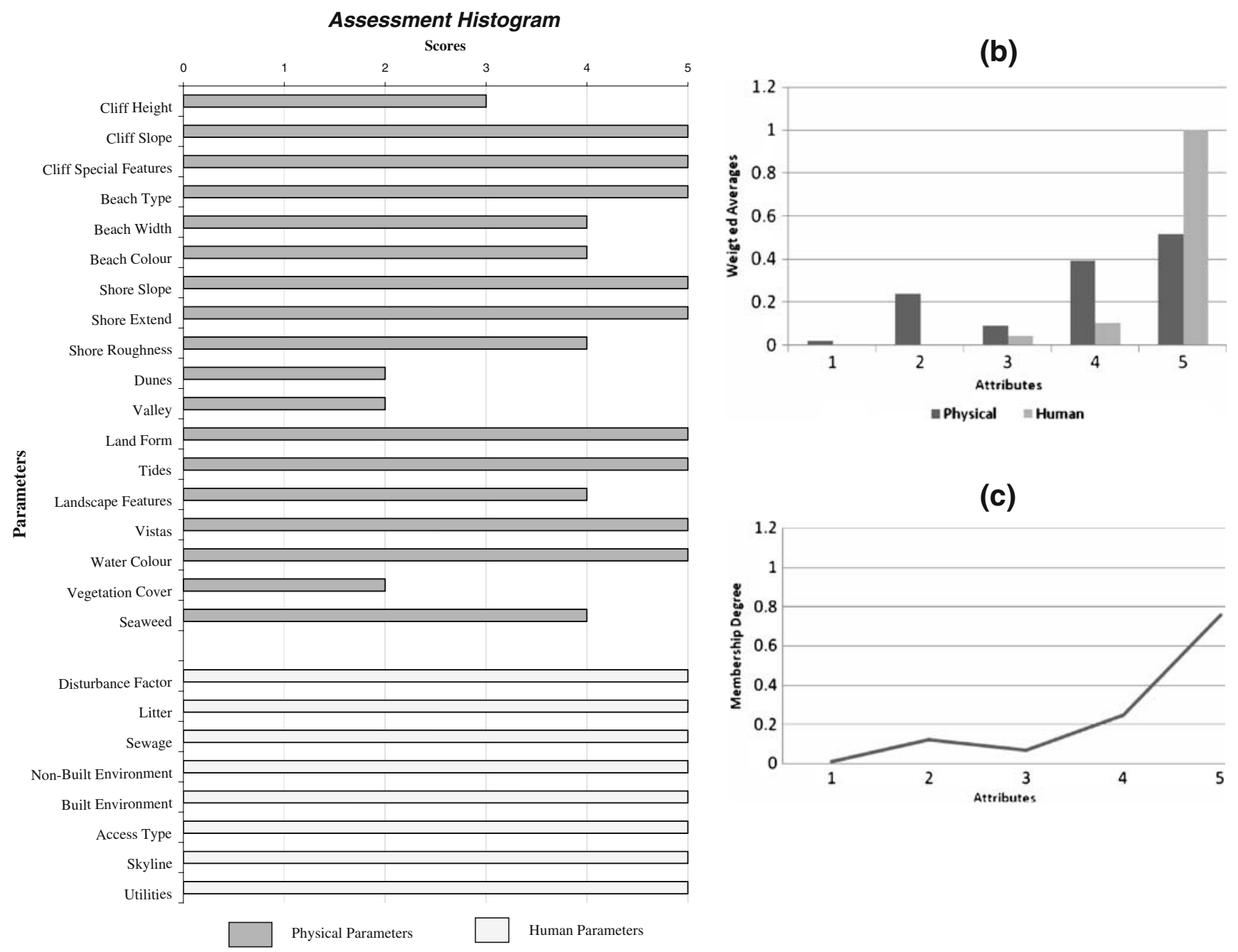

Fig. 4 Histogram (a), weight averages (b) and membership degree (c) for the Jiwani site

example, Jiwani (Fig. 4), whilst a left skewed curve reflects a low scenic value, for example Kaka Pir village (Fig. 6).

\section{Results and discussion}

Final scenic values were individually calculated for all seven coastal localities covering a variety of conditions present in coastal Pakistan through the D parameter,, which classified selected localities into three different classes with progressive lower scoring from class 1 to class 3 (Fig. 7).

\section{Class 1 sites}

Three sites namely Jiwani, Miani Hor and Pasni Astola Island having a $\mathrm{D}$ value $\geq 0.85$ (Fig. 7) qualified for this classification. These sites were extremely attractive natural sites with a very high landscape value.
At Jiwani (Fig. 4) all human parameters scored five (excellent). The beach was located in a beautiful natural environment free from litter and domestic sewage. A small residential area (five to seven houses) inhabited by a single family existed near the coast. The houses were constructed from locally available material which blended well with the natural surroundings. The residential area was also not visible from the beach area. The beach area was surrounded by a moderate cliff on one side and irregular small rocky shore area on the other side backed by a dry valley. An historical lighthouse was present on the cliff top. The natural surrounding provided an attractive vista, open almost on three sides. Water colour was clear blue. Few scattered seaweed remnants were recorded on the beach while scrub vegetation was present behind the high tide mark.

Miani Hor, a site with no cliff, was characterised with a spectacular vista open on four sides. The water colour was green or grey blue with poor visibility probably due to nearby 
(a)

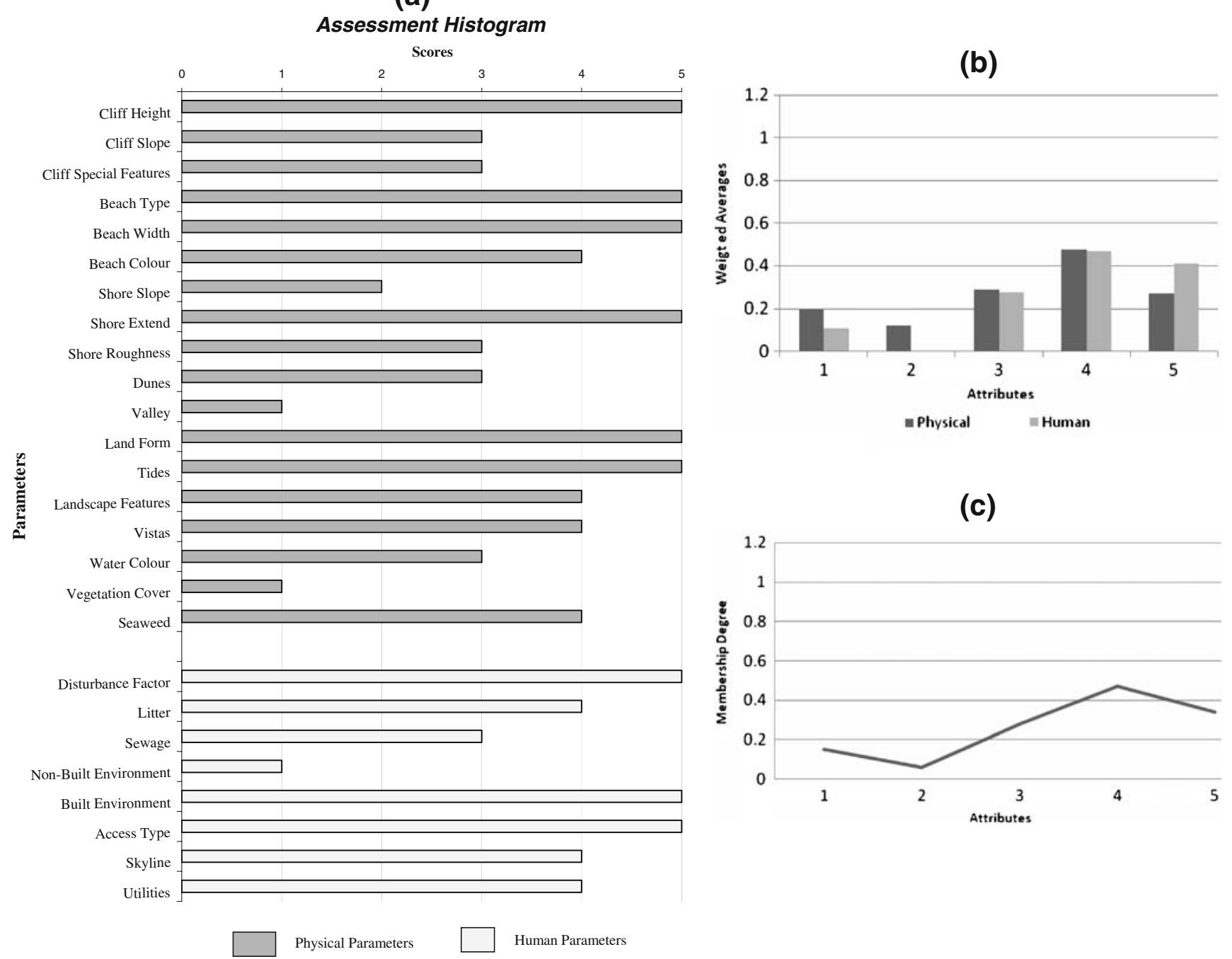

Fig. 5 Histogram (a), weight averages (b) and membership degree (c) for Mubarak village

mud flats or silt laden freshwater inflow into Miani lagoon. With the exception of a parking area visible from the coast, the remaining human parameters were excellent. Utilities, for example power lines and poles, existed but were not an obstacle to coastal scenery. Most local houses were traditionally built in harmony with the natural environment (Plate 1).

Pasni Astola Island, an un-inhabitant island, was characterised with a cliff, sand beach and a small eroded rocky portion (Plate 2). Water colour was clear turquoise, virtually free from all effluent. The beach area had a magnificent vista open on three sides. Seaweed was rarely observed. Almost all human parameters with the exception of the non-built environment were recorded as excellent for the Island.

\section{Class 2 sites}

Mubarak Village was the only site that qualified for this classification (Fig. 5). The beach area was dominated by sand with small rocky portion characterised with smooth rocks. The shore area was less polluted than other urbanised beaches of Sindh province. The water colour was green and the vista was wide open on three sides. Shrub vegetation was observed behind the high tide mark, while few scattered seaweed were also seen on beach area. Human parameters were excellent with the exception of few scattered plastic bags (litter) and a sewage drain recorded in the backshore area. Houses are traditionally built from locally available material (Plate 3 ).

\section{Class 3 sites}

This class included Kaka Pir village, Harjana village and Keti Bandar. Physical and human parameters of Kaka Pir village (Fig. 6) were under the severe influence of Karachi city. The sandspit area contiguous to Kaka Pir village experienced heavy tourism activities on weekends. The 


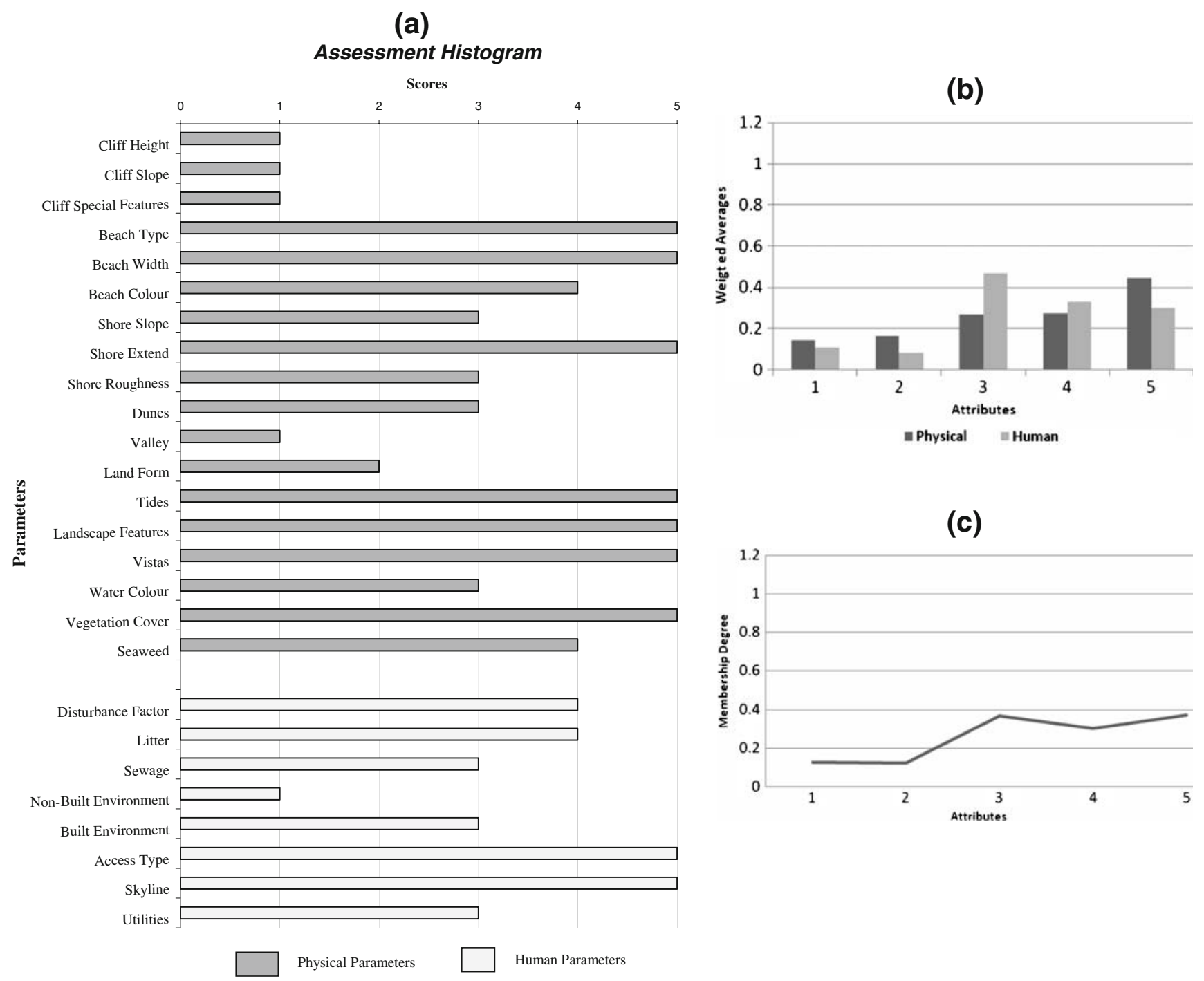

Fig. 6 Histogram (a), weight averages (b) and membership degree (c) for Kaka Pir village

beach was exposed to an open sea with a magnificent vista (Plate 4), however, recreational huts and litter at the back area were major negative human parameters (Plate 5).

Fig. 7 D-values of evaluated sites

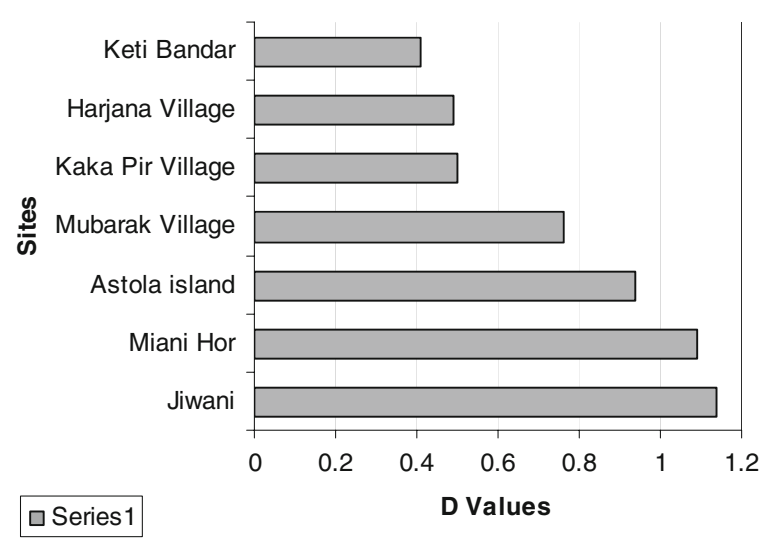

Both Harjana village and Keti Bandar recorded almost similar physical and human parameters. Both sites are located along the rural coast of Sindh province. These localities were less frequently visited by tourists. Sewage

Key:

Class 1 having $\mathrm{D}$ value $\geq 0.85$ Class 2 having D value $>0.65$ and $<0.85$

Class 3 having $\mathrm{D}$ value $>0.4$ and $<0.65$ 


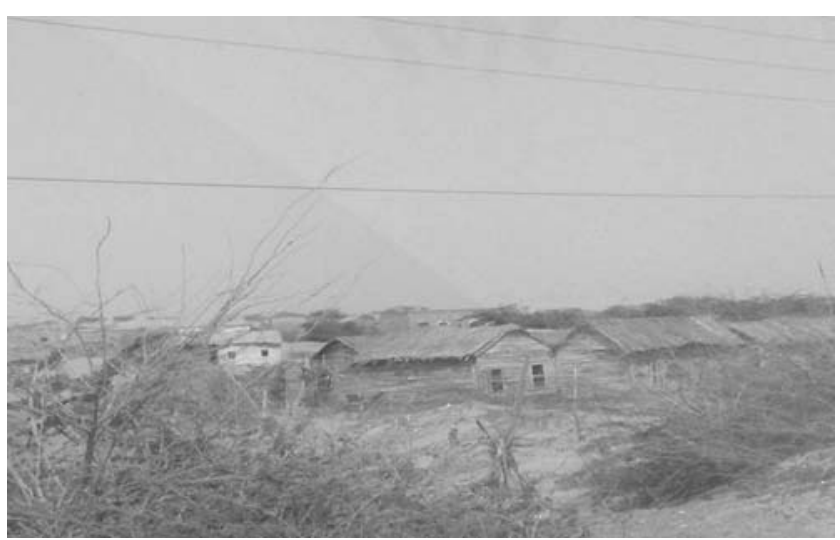

Plate 1 Skyline-Miani Hor site

drains, both from local and distant sources, were common. Utilities such as power lines, poles, roads structures, and un-planned coastal settlement collectively contributed to an un-attractive skyline.

As opposed to the ongoing massive infrastructure based coastal tourism projects, base line information collected by the authors has shown that some ecologically sensitive coastal areas of the country have greater potential for small scale ecotourism. An ecotourism concept is an ethics based approach to tourism (Wright 1993; Bjork 2000; Weaver 2005) and is originally defined as: '...travelling to relatively undisturbed or uncontaminated natural areas with the specific objective of studying, admiring, and enjoying the scenery and its wild plants and animals, as well as any existing cultural manifestations (both past and present) found in these areas' (Ceballos-Lascurain 1987). In addition to natural and cultural resources, ecotourism stresses scenic grandeur. Several coastal tourism studies (for example Morgan and Williams 1995; Morgan 1996; Micallef et al. 1999; Unal and Williams 1999) also realised that coastal scenery can provide competitive advantages especially in rural and remote regions.

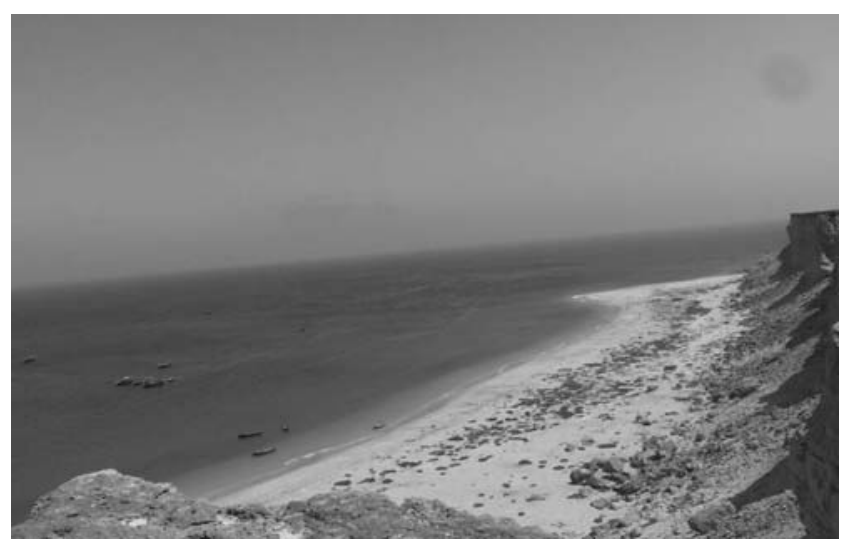

Plate 2 Cliff at back area at Pasni-Astola Island

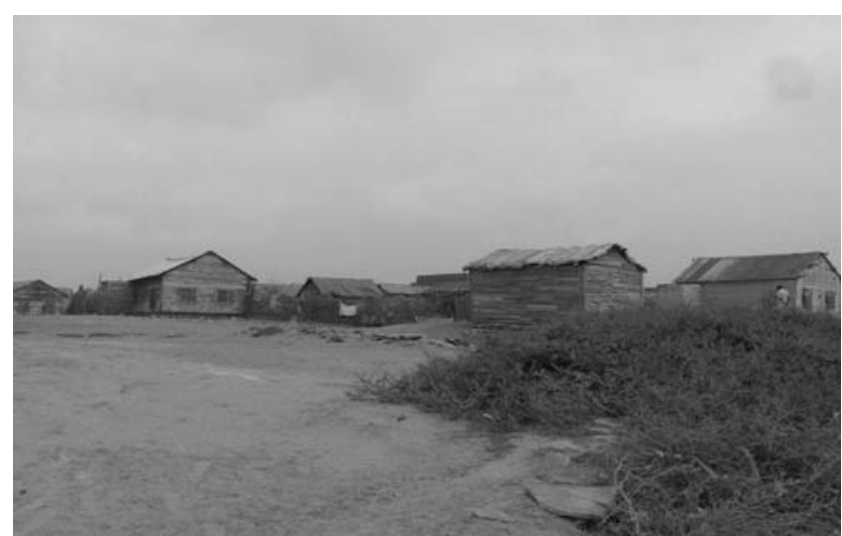

Plate 3 Traditional houses and shrub vegetation on beach at Mubarak Village

Tourism-related concerns are conspicuous by their relative absence in Agenda 21, the Framework Convention on Climate Change and the Convention on Biological Diversity. However, they later become the subject of several official, albeit non-binding, international declarations e.g. the UNEP Environmental Programme of 1995, and UNESCO's 18-point "Charter on Sustainable Tourism" announced in Lanzarote in 1995.

A key attraction of tourism, particularly within a developing country, is that it exhibits a broad range of linkages to other industries and indirectly affects income and employment generation. It also produces its share of qualified jobs and unqualified jobs filled by local people who often lack specific training. It is relatively job intensive in terms of turnover volume to invested capital. What distinguishes tour operators and hotels/guesthouses of nature and cultural tours in developing nations from the increasing trend towards global tourism concentration is that they are mainly highly-specialised, small/medium enterprises that do not really have access to major financial capacities. Nevertheless, large-scale tourism enterprises are

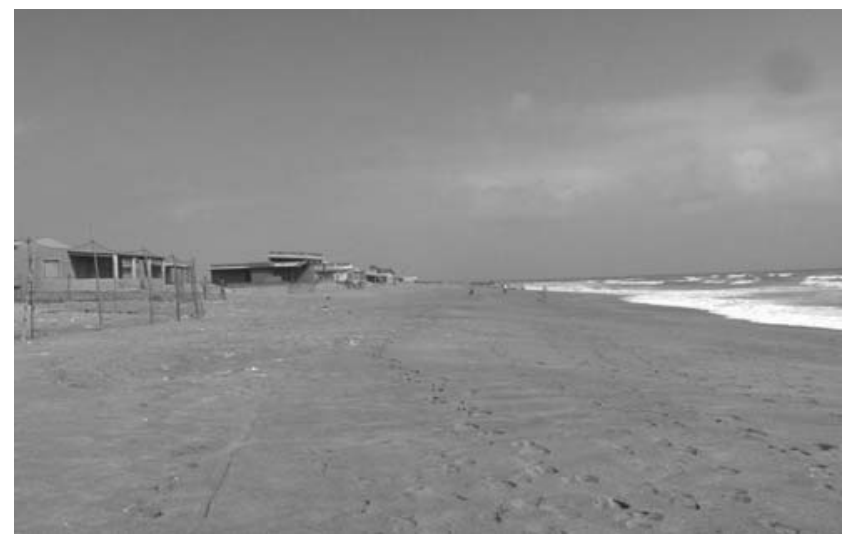

Plate 4 Built environment at Kaka Pir Village 


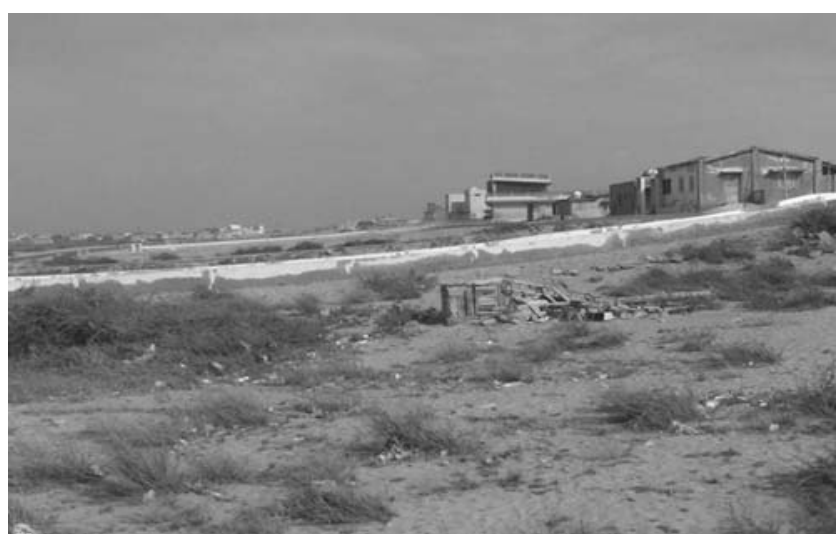

Plate 5 Urban influence on Kaka Pir Village (litter on back area of sand beach)

also increasingly turning to nature and cultural tourism as a means of diversifying.

Any tourist product is a combination of original and derived offerings. The former consists of:

- Natural attractions (e.g. landscapes i.e. scenery, climate, water, beaches, wildlife, vegetation).

- Cultural attractions (e.g. historic, religious or especially typical architectural monuments, traditional handicrafts or other economic products, folklore, festivals, everyday culture, hospitality, special dishes, etc.).

The above bulleted points are rendered accessible and available in order to be utilisable for tourism. This is possible with derived offerings which consist of:

- Transportation facilities.

- Holiday facilities (accommodations, food, shops, entertainment and other facilities necessary for tourism activities, such as hiking paths).

- Mediating facilities (travel agents, tour operators, tourist information offices).

As a sustainable development option, tourism must be planned and managed for wider socio-economic benefits. As an example, tourism attractions and activities relating to natural coastal settings in beautiful locations are important means for spreading benefits to local residents.

However, fundamental tourist framework conditions anywhere in the world demand:

- The presence of a basic transportation infrastructure (international airport, road network, runways).

- Simple immigration and currency regulations (important for tours that include border crossing).

- Personal safety for the tourist (protection from crime, political unrest, harassment from police/military).

- Relatively low health risks (existence of basic medical services, no epidemics).

- Some aspects of natural/cultural features.
Sadly, in Pakistan's case, the absence or lack of certainty concerning most of the above bulleted points has the potential to negate the tourism appeal of the coastal area which, as shown in this paper, exhibits some spectacular scenery. There is a clear message of economic potential being thwarted by political instability, safety and security concerns, and social barriers.

\section{Conclusions}

Comparative assessment between aspects of the Pakistan tourism industry and that within the Mediterranean revealed major differences: neglected values of natural and cultural assets; passive role of potential stakeholders in tourism and lack of destination communities' involvement. This paper addresses the neglect that exists in assessment of the natural beauty of the coastal strip in particular and emphasises the fact that the coastal scenic evaluation technique is equally applicable in developing countries as developed ones.

High income groups or international markets are difficult to capture because of competitive nearby regional markets (for example Dubai) and existing safety and security concerns for foreign tourists. However, both local and national tourism has a growing potential for coastal tourism in the country which is much less realised than the higher income group market. Baseline information collected on natural and cultural resources during fieldwork in Pakistan, has shown that coastal provinces have some ecologically sensitive and scenic areas with a potential for small scale coastal tourism, as opposed to ongoing large scale infrastructure based projects.

Scenic values of the investigated sites were attributed to the influence of rural and/or urban environment on their relevant human parameters. For example, study sites such as Jiwani, Miani Hor, Pasni Astola Island and Mubarak village - remote rural sites away from the urbanised environment, were rated high on their human parameters and subsequently classified as either Class 1 or Class 2 sites. Although Harjana village and Keti Bandar were rural sites, their human parameters were under the severe influence of urban sourced factors. Similarly, the human parameters of Kaka pir village were also directly influenced by the Karachi metropolitan area and all these sites were classified as Class 3.

Finally, scenic values of remote rural coastal locations in Pakistan have an immense potential for coastal tourism development, however, coastal scenery of urbanised or remote rural sites with low rated human parameters can be improved for tourists' attractions through management of local or distance sourced factors. The ease of application and results obtained on the Pakistani coastline clearly support the claim that pilot studies first carried out in the 
Mediterranean had determined evaluation criteria that truly represent a 'universal' coast and thus further strengthens the international scope of this technique.

Acknowledgements We are grateful to two unknown reviewers whose comments helped tighten this paper appreciably.

\section{References}

Benoit G, Comeau A (2005) Eds. A sustainable future for the Mediterranean, EARTHSCAN

Bjork P (2000) Ecotourism from conceptual perspective, an extended definition of a unique tourism form. Int J Tour Res 2:189-202

Ceballos-Lascurain H (1987) The future of "ecotourism". Mexico Journal January 13-14

Clark JR (1996) Coastal zone management handbook. Lewis, Boca Raton

DHA-Waterfront Developments Master Plan (2003) Pakistan defence officers housing authority, Karachi (Draft)

Ergin A, Williams AT, Micallef A, Karakaya ST (2002) An innovative approach to coastal scenic evaluation. In: Ozhan E (ed) Beach management in the Mediterranean and Black Sea, MEDCOAST. Middle East Technical University, Ankara, pp 215-226

Ergin A, Karaesmen E, Williams AT, Micallef A, Karakaya ST, Dedeoglu MR (2003a) Turkish coastal scenery evaluation: the application of fuzzy logic mathematics at selected sites, Electronic publishing (CD Rom), Paper 164, (13 pages), Proc. of the 6th International Conference on Coastal and Port Engineering in Developing Countries, "Engineering the Coastal Environment", COPADEC 6. The Permanent Secretariat of COPEDEC, c/o Lanka Hydraulic Institute, John Rodrigo, Mawatha, Katubedd, Morutuwa, Sri Lanka

Ergin A, Micallef A, Williams AT (2003b) Coastal scenic evaluation-a pilot study of some Dalmatian areas. Report commissioned by the WWF/MedPO, Rome, p 109

Ergin A, Karaesmen E, Micallef A, Williams AT (2004) A new methodology for evaluating coastal scenery: fuzzy logic system. Area 36(4):367-386
Ergin A, Williams AT, Micallef A (2006) Coastal scenery: appreciation and evaluation. J Coastal Res 22(2):958-964

Houston JR (2002) The economic value of beaches-A 2002 update. Shore Beach 70(1):3-10

Leatherman SP (2001) Social and economic costs of sea level rise. In: Douglas BC, Kearney MS, Leatherman SP (eds) Sea level riseHistory and consequences. Academic, San Diego, pp 181-223

Lencek L, Bosker G (1998) The beach: The history of paradise on earth. Viking Penguin, New York, p 310

Micallef A, Williams AT (in press) The health of Mediterranean beaches. UNEP, PAPRAC, Split publication

Micallef A, Morgan R, Williams AT (1999) User preference and priorities on Maltese beaches: Findings and potential importance for tourism. In: Randazzo G (ed) Coastal environmental management. EUCC, Italy electronic pub

Morgan R (1996) Beach user opinions and the development of a beach rating scale. Unpublished $\mathrm{PhD}$ Thesis. University of Glamargon, Wales, pp 336

Morgan R, Williams AT (1995) Socio-demographic parameters and user priorities at Gower beaches, UK. In: Healy MG, Doody JP (eds) Directions in European coastal management. EUCC and Samara, Tresaith, pp 83-90

Najam A (2007). 'Sahil Bachao': The battle for Karachi waterfront. http://pakistaniat.com (accessed 18th April 2007)

Tourism in Pakistan (2006) Government of Pakistan. Ministry of Tourism, Islamabad, p 24

Unal O, Williams AT (1999) Beach visits and willingness to pay: Cesmepenisula, Turkey. In: Ozhan E (ed) Medcoast99-EMECS99 Joint conference. Land Ocean interactions: Monitoring coastal ecosystems. MEDCOAST, Middle East Technical University, Ankara, pp 1149-1162

Weaver DB (2005) Comprehensive and minimalist dimensions of ecotourism. Ann Tour Res 32(2):439-455

Williams AT, Ergin A (2006) Scenery bathing area registration and evaluation of selected beaches along the coastal province of Nador, Morocco. Report for the European Union for Coastal Conservation, pp 44

Wright P (1993) Ecotourism: ethics or eco-sell? J Travel Res XXXI(3):3-9

WTO (World Tourism Organisation) (2001) Leading the world's largest industry. http://www.world-tourism.org/aboutwto.html. Date accessed: 24/3/09 